\title{
Reflexões acerca da descriminalização do aborto
}

\section{A criminalização do aborto em questão.}

MATOS, Maurílio Castro de.

São Paulo: Almedina, 2010. 110 p.

Assistente social de um hospital público no Rio de Janeiro e professor da Universidade Estadual do Rio de Janeiro, Maurílio Castro traz, em seu livro, um tema bastante polêmico para refletirmos. A obra que ora se apresenta é fruto da sua tese de doutorado, a qual teve seu estágio de pesquisa realizado em Portugal, no ano de 2007, momento em que estava no auge, nesse país, o debate em torno da descriminalização do aborto. Tal fato permitiu uma maior aproximação do autor com a discussão em torno da Interrupção Voluntária da Gravidez (IVG).

É uma obra que contribui para o debate sem moralismos e preconceitos ao apresentar aspectos da realidade sobre os quais não se pode deixar de refletir. Nela o autor abordará a temática numa perspectiva política, indicando a necessidade de sua descriminalização, haja vista que considera o aborto uma questão de efetivação dos direitos humanos das mulheres, além de ser um grande problema de saúde pública, implicando na morbimortalidade materna.

O livro divide-se em quatro partes: uma breve introdução, na qual faz um resgate histórico do aborto; o desenvolvimento, dividido em dois capítulos, trazendo uma análise da realidade brasileira e portuguesa, respectivamente; e, ao final, contempla os seus leitores com um rico apêndice, apresentando elementos como obras de arte, filmes e documentários, que poderão ser consultados para dar continuidade ao debate.

Na introdução, Matos (2010) apresenta uma análise do aborto na história da humanidade, apresentando-o como sendo uma prática antiga que, até certo período, foi realizada mais livremente, pelo fato de o corpo da mulher ser considerado foro privado. Esse quadro irá se alterar na passagem do século XVII para o XVIII, contribuindo para isso: a) o desenvolvimento científico, no qual o desconhecimento em torno do corpo da mulher passa a ser superado; b) o processo de Revolução Francesa, momento no 
qual começou a preocupação com nascimento das pessoas para servir a nação; $c)$ e a questão demográfica quanto ao controle para regressão ou expansão da natalidade.

No plano mundial, foi a partir do movimento de maio de 1968 que a defesa da legalização do aborto entrou no cenário público como bandeira do movimento feminista. Desde então as legislações de diversos países vêm sendo revisadas. Por envolver determinações vinculadas à moral, à política e à ideologia, existem aspectos que devem ser considerados na análise da realidade de cada país.

No primeiro capítulo, o autor trata da questão do aborto na especificidade brasileira, contextualizando-a historicamente e expondo os desafios para sua descriminalização. Faz um panorama histórico desde o Brasil Colônia aos anos 2000. Mostra que o controle da prática no início da colonização se deu com o objetivo de povoação e proteção do território e que a primeira legislação punitiva da prática data de 1830; até então, tinha-se apenas a condenação moral da lgreja. De 1890 a 1940, havia o Código Penal da República e, de 1940 aos dias atuais, há o Código Penal, o qual permaneceu inalterado até fins dos anos de 1980, apesar de tentativas de sua revisão. Mesmo assim, o autor destaca alguns pontos, como o Programa de Atenção Integral à Saúde da Mulher (PAISM) no governo Figueiredo (1979/1985), que tratava o planejamento familiar como forma de evitar o aborto, e a implantação, em 1989, em São Paulo, do primeiro serviço de aborto legal no Brasil.

Salienta que, após a Constituição de 1988, vários projetos favoráveis à descriminalização foram apresentados, sem êxito, excetuando-se a aprovação da Lei n. ${ }^{\circ} 8.921 / 94$, que garantiu o abono de faltas ao trabalho à mulher que passa pela situação de abortamento. Nos anos 2000, 0 debate aumentou e houve algumas conquistas, como a deliberação pela importância de rever a legislação concernente ao aborto com a Conferência Nacional de Políticas para as Mulheres e a edição da Norma Técnica de Atenção Humanizada ao Aborto, nos anos 2003 e 2004, respectivamente.

O autor apresenta dados da Pesquisa Nacional do Aborto realizada em 2010, para justificar a necessidade de reformular a legislação, já que pôde ser abstraído da pesquisa que, apesar da proibição, o aborto é comum na realidade de mulheres brasileiras. Apesar desses dados, os antagonismos clássicos permanecem, sendo a discussão gerada em torno de três elementos básicos: o início da vida humana, o direito da mulher em decidir se quer ou não manter a gestação e a responsabilidade do Estado em definir sobre o aborto.

Quanto à existência de um debate polarizado, são apresentados cinco aspectos que fazem com que seja inviabilizada a concretização de uma lei descriminalizando o aborto. O primeiro diz respeito à dificuldade em torno das votações dos projetos de lei apresentados ao Congresso Nacional, os quais não vêm obtendo êxito, fato em que pesam argumentos morais e religiosos. O segundo está relacionado ao papel da Igreja Católica e sua reação à questão, sendo exemplo disso a Campanha da Fraternidade promovida em 2008 com o tema "Escolhe, pois, a vida". O terceiro remete ao posicionamento do Superior Tribunal Federal quanto à gestação de fetos anecéfalos, o qual apresenta avanços e recuos, isso porque depende do posicionamento do juiz que analisa a situação. O quarto está vinculado à intolerância em torno do debate sobre a descriminalização do aborto, assumindo uma postura de negação do diálogo, buscando a penalização daqueles que defendem ou recorrem à prática. $O$ quinto aspecto levantado remete às contradições na posição adotada pelo Governo Federal, que ora apresenta posicionamento progressista, como a proposta de descriminalização do aborto posta no Programa Nacional de Direitos Humanos (PNDH3) em 2009, ora regressista, como a revisão desse ponto do PNDH em virtude de críticas por parte da ala conservadora, o qual, por decretos presidenciais, foi alterado, não se tratando mais de descriminalizar o aborto, mas tratá-lo como uma questão de saúde pública, devendo ser garantido acesso ao serviço de saúde às mulheres que dele necessitar.

Para 0 autor, enquanto o aborto for visto apenas como um problema de saúde pública a questão não será resolvida no Brasil, haja vista a necessidade de se fazer uma discussão em torno de outros elementos, como sobre o ser homem, o ser mulher e o exercício da sexualidade.

No segundo capítulo do livro, o autor analisa a realidade de Portugal expondo o processo de descriminalização e a implantação do serviço de aborto legal no serviço público de saúde desse país e analisando o Sistema Nacional de Saúde (SNS).

A política de saúde de Portugal possui tensões semelhantes à brasileira. Apesar disso, uma diferença salta aos olhos: enquanto em Portugal as mudanças são realizadas por alterações legais, no Brasil, assiste-se ao sucateamento do serviço público. 
Em Portugal, até 1976, podem ser visualizadas duas fases: a primeira vai até 1945 , voltada para ações sanitárias e alguns seguros sociais obrigatórios, e a segunda, de 1946 a 1976, com a criação das Caixas de Previdência. A partir de 1976, o sistema de saúde passa por uma reestruturação, fruto da constituição democrática desse ano. Foi criado e regulamentado, em 1979, o Serviço Nacional de Saúde, com oferta dos serviços totalmente gratuitos.

Com a ofensiva neoliberal, já em 1989 é alterada a redação da lei para serviços "tendencialmente gratuitos", mas é em 1990, com a revisão constitucional, que é apontada a Reforma do Sistema de Saúde, que vai incidir sobre a participação (responsabilidade dos sujeitos), o financiamento (cobrança de taxas) e a gestão (substituição do Estado por outras instituições). Desde então, várias reformulações vêm sendo feitas no sentido de restringir a responsabilidade do Estado.

No que tange ao debate sobre o aborto, desde a inauguração, em 1976, da fase democrática no país, o tema veio várias vezes à tona, caracterizando-se pela polarização em torno da questão. Houve dois plebiscitos para votar a descriminalização do aborto. O primeiro ocorreu em 1998, sem êxito. O segundo, em 2007, saindo vencedora a proposta de descriminalização até a $10^{a}$ semana de gestação, sendo referendado pela Lei n. 16/2007, de 17 de abril de 2007, que entrou em vigor em 22 de abril de 2007. Um fato que pode ter contribuído para esse resultado favorável foi a realização, em 1998, de diversos julgamentos de mulheres que abortaram ou de outras que as auxiliaram.
A promulgação da lei não significou a extinção da polarização no debate. Exemplo disso ocorreu em 2009 quando a ala conservadora encaminhou à Assembleia da República uma petição com mais de 5.000 assinaturas solicitando o retorno à criminalização do aborto. Fato é, segundo Matos (2010), que descriminalizar o aborto foi, em primeiro lugar, um exercício de direitos humanos e, em segundo, possibilitou, por exemplo, uma análise mais precisa sobre a magnitude dos dados sobre o aborto, bem como os impactos na mortalidade materna.

A questão é que o consenso está longe de existir e talvez nunca se chegue a ele. No entanto, não se pode deixar adormecer a discussão na realidade brasileira enquanto milhares de mulheres se violentam e/ou morrem anualmente ao interromperem uma gravidez clandestinamente. Para além de uma questão de saúde, o direito ao aborto se insere no rol dos direitos humanos e na busca de uma sociedade pautada na equidade entre homens e mulheres, pois se vê que as relações de gênero estão intrinsecamente vinculadas à questão da criminalização do aborto, haja vista que a desigualdade entre homens e mulheres corrobora para um debate unilateral, o qual responsabiliza a mulher por praticá-lo.

Esse livro insere o leitor numa leitura fácil, agradável e elucidativa dos motivos que devem ser levados em conta na revisão das legislações punitivas, visando à descriminalização do aborto. É recomendado para quem já se debruça sobre a temática, bem como para os leigos que desejam uma primeira aproximação.

Brunilla Thaís Queiroz de Melo Universidade Federal do Rio Grande do Norte 